\title{
虚血性腎障害を伴ったStanfordB型急性大動脈解離に対し， TEVARに末梢血管用ベアステントを併用した1例
}

\author{
佐賀 俊文, 堀 優人, 御子柴晴樹, 浦田 雅弘
}

要 旨: 症例は 45 歳, 男性。他院より遠位弓部〜腹部大動脈に及ぶ急性大動脈解離 $\mathrm{B}$ 型を認め, 当院へ救急 搬送された。腹部は偽腔が血栓化し，真腔狭窄により急性腎不全を発症していた。ステントグラフト挿入（TEVAR）を施行したが，真腔拡張は得られず，末梢血管用ベアステントを同部位に留置した。Entry閉鎖を行って も高度な真腔狭窄が残存したが, 自己拡張型のベアステントを併用し, 致命的な腎障害を回避することができ た。(J Jpn Coll Angiol 2020; 60: 145-149)

Key words: type B aortic dissection, malperfusion, TEVAR

受付：2020年 5 月 28 日 受理： 2020 年 6 月 25 日 公開：2020年 8 月 10 日

\section{序言}

Complicated type の stanford B 型急性大動脈解離 （TBAD）に対し胸部ステントグラフト内挿術（TEVAR） によって central repairを行った場合, 真腔の拡張と偽腔 圧の低下が期待される。しかし，偽腔血栓によって真腔 狭小が改善しない症例を経験した。このような症例に対 し, 自己拡張型の末梢血管用ベアステントを追加し, 真 腔の確保によって腎虚血の改善を認めたため報告する。

\section{症例}

症 例 : 45歳, 男性

主 訴：対麻㿁, 腎障害

現病歴: 数日前, 車の運転中に強い背部痛を自覚し, その際は15分ほどの安静で症状が軽快した。2020年 4 月23日，呼吸苦にて近医を受診し，急性心不全の診断 にて緊急入院となった。翌4月24日朝より突然の両下肢 の麻痺が出現した。造影 $\mathrm{CT}$ 検査にて TBAD と診断され, 加療目的に当院搬送となった。

既往歴：高血圧に対し内服加療を行っていたが, 数力 月前より自己中断

家族歴：特記事項なし

生活歴：飲酒, 機会飲酒, 喫煙 20 本/日，22 45歳

新久喜総合病院心臟血管外科

doi: 10.7133 jca.20-00023

(c)) BY-NC-ND
入院時現症：身長 $175 \mathrm{~cm}$, 体重 $95.5 \mathrm{~kg}$, BMI $31.2 \mathrm{~kg} / \mathrm{m}^{2}$, 血圧 $128 / 72 \mathrm{mmHg}$ 左右差なし, 脈拍 $131 \mathrm{bpm}$ (整), $\mathrm{SpO}_{2}$ 94\%（マスク $5 \mathrm{~L}$ ), 来院時両下肢に麻疩あり, 歩行不可

入院時血液検査所見 : WBC $22,400 / \mu \mathrm{L}, \mathrm{Hb} 13.2 \mathrm{~g} / \mathrm{dL}, \mathrm{Plt}$ $44.5 \times 10^{4} / \mu \mathrm{L}$, PT-INR 1.3, APTT $31.2 \mathrm{sec,} \mathrm{フィブリノーゲ}$ ン $514 \mathrm{mg} / \mathrm{dL}$, 血中 FDP $21.4 \mu \mathrm{g} / \mathrm{mL}$, D-dimer $9.5 \mu \mathrm{g} / \mathrm{mL}$, TP $6.7 \mathrm{~g} / \mathrm{dL}$, Alb $3.5 \mathrm{~g} / \mathrm{dL}$, AST $21 \mathrm{U} / \mathrm{L}$, ALT $30 \mathrm{U} / \mathrm{L}$, LDH 290 U/L, $256 \mathrm{U} / \mathrm{L}, \mathrm{T}-\mathrm{Bil} 0.9 \mathrm{mg} / \mathrm{dL}$, BUN $91.7 \mathrm{mg} / \mathrm{dL}$, CRE $6.65 \mathrm{mg} / \mathrm{dL}, \mathrm{Na} 137 \mathrm{mEq} / \mathrm{L}, \mathrm{K} 4.3 \mathrm{mEq}, \mathrm{Cl} 94 \mathrm{mEq} / \mathrm{L}$, CRP $15.17 \mathrm{mg} / \mathrm{dL}$, BNP $451.4 \mathrm{pg} / \mathrm{mL}$, eGFR $8.2 \mathrm{~mL} / \mathrm{min} / 1.73 \mathrm{~m}^{2}$ 胸部レントゲン所見：心胸郭比 $58 \%, \mathrm{CP}$ angleやや dull 両肺野の透過性低下。右肺野にKerley’s B lineを認める。 心エコー所見：EF 62\%, asynergy (-), 弁膜症 $(-)$,

CT 所見：TBADを認め, 遠位弓部〜左総腸骨動脈近 位側にかけて解離が認められた。左鎖骨下動脈末梢 $1 \mathrm{~cm}$ にentryを認めた。Th10以下, 腹部大動脈レベルでは真 腔は非常に狭く, 偽腔は血栓化していた。腹腔動脈, SMA，両側腎動脈，IMAはいずれも真腔分岐していた。 腹部臟器の分枝血管には解離は及んでいなかった。腎臓 の造影は両側ともに低下していた。両側外腸骨〜下肢動 脈の描出は軽度低下していた（Fig. 1)。

入院後経過 : 真腔の高度狭窄による腎血流低下にて虚 血性腎不全を発症し，心不全を合併していると判断し，

TEVARによる central repairの方針となった。

手術所見：全身麻酔下に手術を開始した。右総大腿 動脈より VALIANT Navion（Medtronic, Santa Rosa, Calif) VNMC3428C207TJ と VNMC3125C207TJをZONE2から 


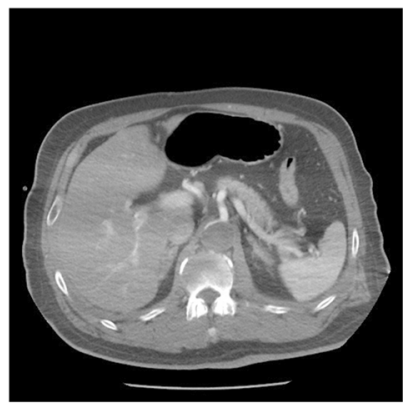

(1)

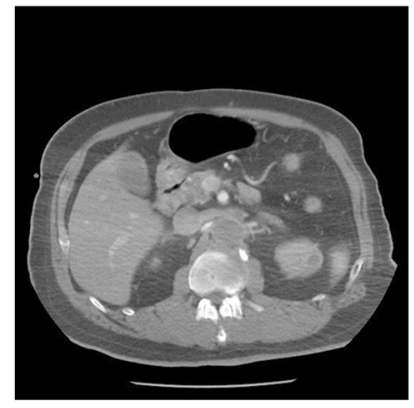

(2)

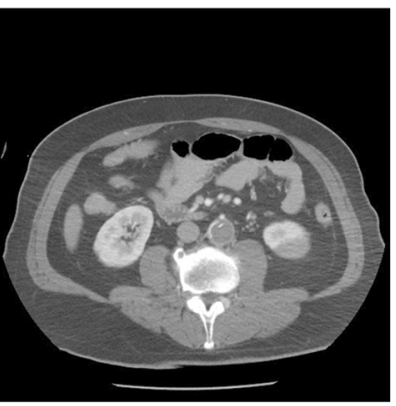

(3)

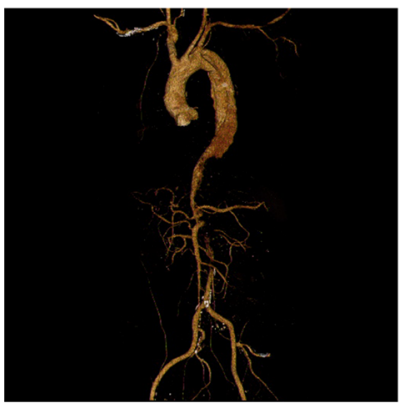

(4)

Figure 1 Pre-operative enhanced computed tomography (eCT)

(1) Celiac artery bifurcation level. (2) Renal artery bifurcation revel. (3) Inferior mesenteric artery bifurcation level. (4) Three dimensional CT. All slice show narrow true lumen of abdominal aorta.

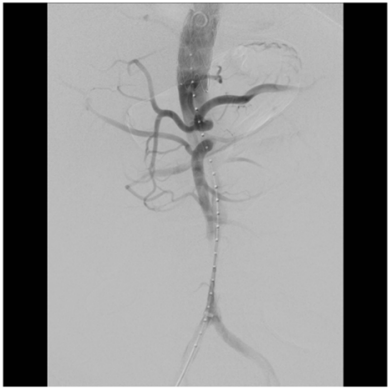

(1)

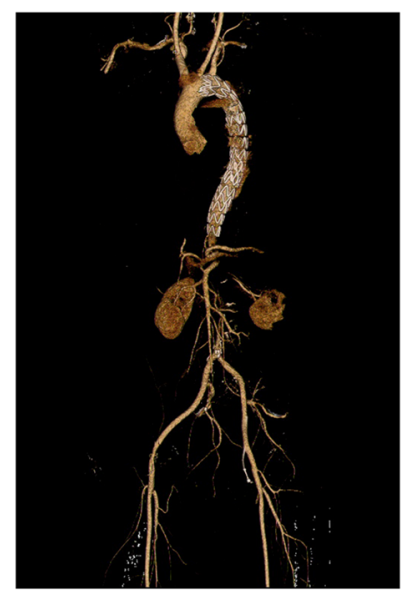

(2)
Figure 2 (1) Intra-arterial DSA and (2) three dimensional CT after TEVAR

Inspite of success of central repair, true lumen of abdominal aorta is still very narrow.

CA直上まで中枢より留置した。確認造影で entryから の偽腔血流は消失したが, 術前 CTにて高度真腔狭窄を 認めていたTh10レベルから腹部大動脈の真腔拡張は得 られなかった（Fig. 2)。そのため, ステントグラフト の末梢から腹部大動脈末梢まで, 未梢血管用ベアステ ントのエピックバスキュラーステント（Boston Scientific Corporation, Marlborough, MA, USA） $12 \mathrm{~mm}$ 径のものを 3 本 $(12 \mathrm{~mm} \times 60 \mathrm{~mm} \times 2$ 本, $12 \mathrm{~mm} \times 40 \mathrm{~mm} \times 1$ 本 $)$ を連結 して追加留置を行った。バルーン拡張を施行し, 造影に て軽度両側腎動脈, 総腸骨動脈の造影が改善したのを確 認し，治療を終了した。

術後経過：術後よりCHDFを開始した。尿量の確保は 認めていたものの, 術後4日目にCEDFを終了としたが, 腎機能障害が遷延した。そのため術後7日目より再度 CHDFを再開し術後16日目まで継続した。以降はCHDF 終了後も eGFRの大幅な低下を認めず, 術後31日目に
はBUN $25.7 \mathrm{mg} / \mathrm{dL}$, Cre $1.66 \mathrm{mg} / \mathrm{dL}$, eGFR37.4 mL/min/ $1.73 \mathrm{~m}^{2}$ まで回復し, リハビリ病棟へ転棟した。術後 3 日目，11日目，27日目に造影CTにてフォローしたと ころ, 継時的に腹部大動脈の真腔の拡大が認められた (Figs. 3, 4)。術後27日目に下肢の血流の評価を行い, $\mathrm{ABI}$ は右下肢 1.26 左下肢 1.14 と良好であった。総大腿動 脈の下肢動脈エコーによる血流評価では収縮期立ち上 がり時間 (ACT) は右 $94 \mathrm{~ms}$, 左 $83 \mathrm{~ms}$, 最大流速は右 $128 \mathrm{~cm} / \mathrm{s}$, 左 $103 \mathrm{~cm} / \mathrm{s}$, パルスドプラ波形も両側 I型と中 枢の狭窄を示唆する所見は認めなかった。解離の安定 化のため, ベアステントに対する抗血小板薬は使用しな かった。対麻痺に関しては術後も改善を認めず，術後 22 日目に脊髄MRIを施行したところ, 第 11 胸椎レベル での春髄梗塞が認められた。術後 31 日目にリハビリ病 棟へ転棟となった。

\section{考察}

急性大動脈解離のうち, 上行大動脈に解離が認められ ないTBADの割合は36.7〜 41.5\%であり ${ }^{1,2)}$, uncomplicated typeの場合は，急性期を降圧管理とすることで良好 な結果が得られることが知られている。しかし，TBAD の 15.9〜21.9\%は malperfusion, コントロール不良の疼 痛, 破裂, 血管径の拡大等を合併した complicated type であり，外科的治療血行再建や TEVARあるいは人工血 管置換術による central repairが必要となる ${ }^{2,3)}$ 。TBADの malperfusionは腹部臓器と下肢への発症が多いが, 脊髄, 食道にまで多岐にわたって認められる ${ }^{4)}$ 。腹部臓器に合 併した場合の死亡率は 35.7～55.6\% と不良であり ${ }^{1,4,5)}$, その死因の多くは腸管壊死が関係したものであるが，腎 動脈閉塞を合併した場合の死亡率も50\%の死亡率を認 めるとの報告があり ${ }^{6)}$, 積極的治療を必要とする。

解離による臓器虚血の発症機序には, 分枝自体に解 


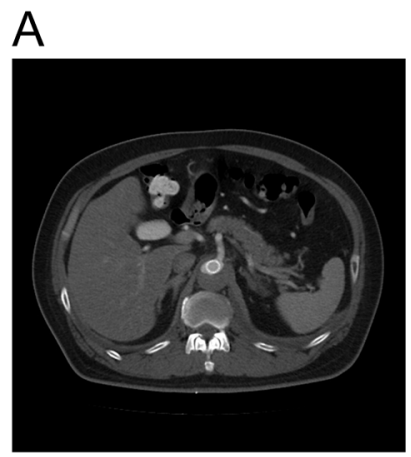

(1)

B

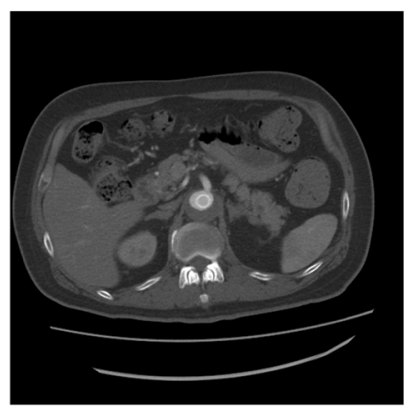

(1)

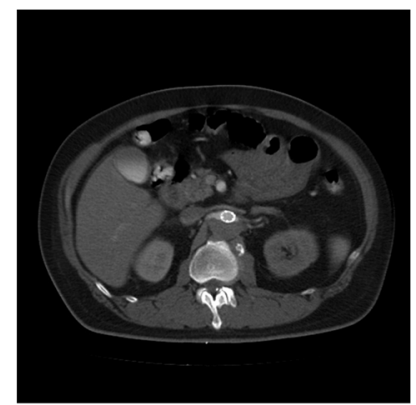

(2)

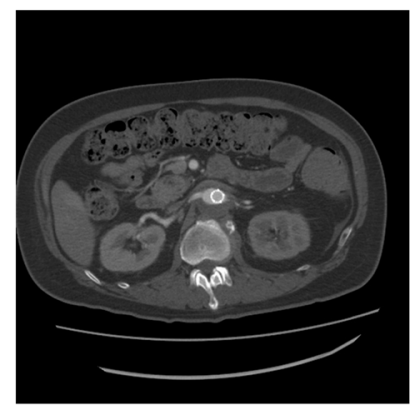

(2)

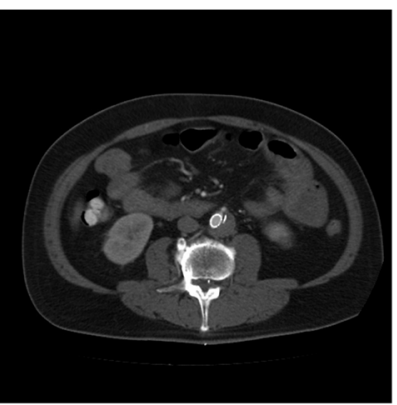

(3)

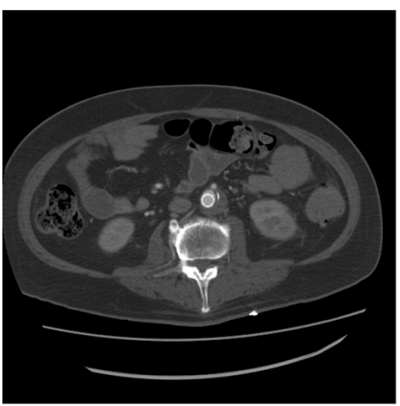

(3)

Figure 3 Post operative enhanced CT, A) post operativeday (POD)3, and B) POD27

(1) (3) number show the same level as Fig. 1. Gradually, true lumen of abdominal aorta was expanded by radial force of bare-stent and got remodeling.

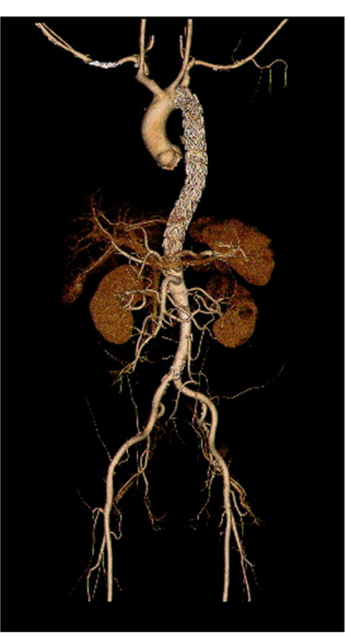

(1)

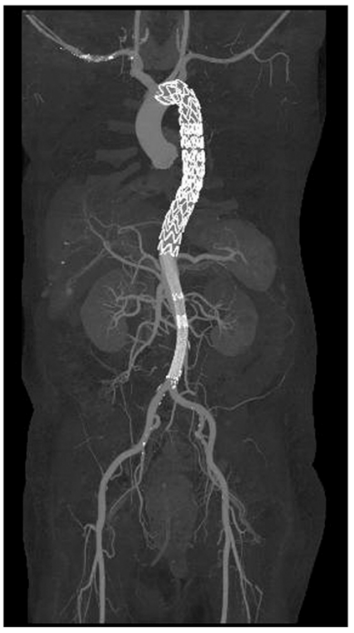

(2)
Figure 4 (1) Three dimensional CT and (2) maximum intensity projection (MIP) at post operative day 27

Ture lumen of abdominal aorta was well-enhanced.

離が進展し，末梢臓器に虚血が及ぶstatic obstruction type と大動脈解離部の偽腔圧が真腔圧よりも高く, 真腔圧 排によって分枝虚血をきたす dynamic obstruction typeに 分類される7)。Static obstruction typeでは虚血を認めた分 枝への非解剖学的バイパスが適応となるが, 分枝内へ
ベアステントを留置し良好な結果を得たとの報告もあ る $^{8)}$ 。Dynamic obstruction typeではTEVARあるいは人工 血管置換術による entry閉鎖, 真腔血流の確保が必要で ある。TBADに対する緊急手術では外科手術と血管内治 療では術後 30 日以内の死亡では外科手術 $33.9 \%$, 血管内 治療 $10.6 \%$ と死亡率に大きな差があることから，近年で はステントグラフトによる治療が第一選択となりつつ ある。本症例の腎虚血はdynamic obstruction typeであり， 虚血の解除にはTEVARによる central repairが良い適応で あると考えた。Entry閉鎖は予定通りなされたが，発症 数日が経過していたため, 盲端である腹部大動脈レベル で偽腔が血栓化しており, 真腔の高度狭窄は改善されな かった。追加治療は外科的手術を行うか, あるいは血管 内治療を追加するか検討したが, 手術死亡率の差, 術式 が腹部の分枝を伴う胸腹部人工血管置換術が必要であ ることを検討し，血管内治療の追加を行うこととした。 真腔拡張のための追加デバイスは (1) Zenith Dssection ${ }^{\circledR}$ エンドバスキュラーステント（TXD）（Cook Japan，東 京), (2)胆管用バルーン拡張型ステント, (3)末梢血管用 自己拡張型ステントを検討した。本症例では血栓の硬 化がやや進行していると考え, TXDおよびエピックバ 
スキュラーステントの radial forceでは十分な拡張が速や かに得られない可能性も考えられた。 Radial forceに関す る公式のデータはいずれのデバイスも公開されていな い。一般的に同一のデバイスであれば外径の小さいもの の方が大きいものよりも大きな radial forceが得られると されているが，XDはステンレス製，エピックバスキュ ラーステントはナイチノール製と材質が異なり，形状や 厚みも異なるため比較検討は難しい。エピックバスキュ ラーステントは院内在庫がある一方，TXDは搬送に1時 間30分を要し，到着を待つことで腎血流障害の時間が さらに長くなるため, デバイス決定には難渋した。末梢 血管用ステントを大動脈へ使用することは適応外使用で あるため, TXDの到着を待ち, TXDの治療効果が認め られない場合に末梢血管用ステントの追加を検討した方 が治療の妥当性が得られたかもしれない。胆管用ステン 卜は解離の狭小化した真腔に留置し，良好な結果を得た 報告が散見されるが9,10)，バルーン拡張型デバイスであ るため, 解離急性期の血管にバルーン拡張を施行するの はさらなる合併症を発生するリスクが高いと判断した。 entry閉鎖によって偽腔の血栓化がさらに進めば，徐々 に偽腔が縮小しリモデリングしていくことが期待された め，自己拡張型のステントを選択することとした。

術後は腎動脈エコーにて腎血流量の評価を試みたが BMI $31.2 \mathrm{~kg} / \mathrm{m}^{2}$ と肥満体型であったため, 正確な評価が 難しかった。尿量が十分に確保されていたため, 生化学 検査と尿量でフォローを継続した。12 mm 径のステント を腹部大動脈に留置した場合，断面積で考えると一方の 総腸骨動脈径が約 $8.5 \mathrm{~mm}$ と同等の血流量となる。実際 の真腔は正円ではなく楕円状に圧排されているため，短 径が $12 \mathrm{~mm}$ となり，やや断面積は大きくなるが，下肢 血流が不十分である可能性が考えられた。結果的には SMA，腎動脈レベルではステント径以上の真腔拡張が 認められ，ABI検査では術後正常でああった。また下肢 エコーにて両側の総大腿動脈の $\mathrm{ACT}$ ，パルス度プラ波 形による評価でも中枢の狭窄，下肢血流不足は認められ なかった。そのため当初はbridging 手術と考えていたが 経過観察としている。今後真腔拡大がさらに進んだ場 合, ベアステントの migration等により抜去が必要になる 可能性があり，慎重なフォローが必要である。

\section{結語}

高度真腔狭窄にて虚血による急性腎不全を合併した
TBADに対し，ステントグラフトと末梢血管ステントを 大動脈に留置し，致命的な腎不全を回避することができ た。

\section{利益相反}

著者および共著者全員が利益相反はない。

付 記

本症例報告は当院倫理委員会の承認を得ている（承認 番号：0070)。

\section{文献}

1) Aiba M, Kawada $T$, Maruta $K$, et al: Surgical treatment for acute aortic dissection associated with end-organ malperfusion. Jpn J Vasc Surg 2003; 12: 581-586

2) Fattori R, Tsai TT, Myrmel T, et al: Complicated acute type B dissection: is surgery still the best option?: a report from the International Registry of Acute Aortic Dissection. JACC Cardiovasc Interv 2008; 1: 395-402

3) Yamashiro S, Arakaki R, Maeda T, et al: Management for treatment of type B aortic dissection. Jpn J Vasc Surg 2014; 23: 687-694

4) Kageyama S, Ohashi T, Tadakoshi M, et al: A case of esophagus rupture caused by acute type B dissection. J Vasc Surg 2015; 24: 818-821

5) Ozawa M, Uchida N, Shibamura H, et al: Strategy for acute type IIIb aortic dissection associated with abdominal-organ malperfusion. J Vasc Surg 2006; 15: 551-558

6) Cambria RP, Brewster DC, Gertler J, et al: Vascular complications associated with spontaneous aortic dissection. J Vasc Surg 1988; 7: 199-209

7) Williams DM, Lee DY, Hamilton BH, et al: The dissectied aorta: percutaneous treatment of ischemiccomplicationsprinciples and results. J Vasc Interv Radiol 1997; 8: 605-625

8) Hughes GC, Andersen ND, McCann RL: Management of acute type B aortic dissection. J Thorac Cardiovasc Surg 2013; 145: S202-S207

9) Ono M, Mizuno A, Komiyama N: Successful endovascular therapy for isolated abdominal aortic dissection involving bilateral common iliac arteries. Ann Vasc Dis 2019; 12: 99-102

10) Giribono AM, Ferrara D, Spalla F, et al: Endovascular treatment of spontaneous isolated abdominal aortic dissection. Acta Radiol Open 2016; 5: https://doi.org/10.1177/ 2058460116681042 


\title{
A Case of Endovascular Repair with Stent Graft and Peripheral Bare Stent for Type B Acute Aortic Dissection with Renal Ischemia
}

\author{
Toshifumi Saga, Yuto Hori, Haruki Mikoshiba, and Masahiro Urata \\ Department of Cardiovascular Surgery, Shinkuki General Hospital, Saitama, Japan
}

Key words: type B aortic dissection, malperfusion, TEVAR

We report a case of a 45-year-old man, who was transported as an emergency case to our institution because of type $\mathrm{B}$ dissection with paraplegia and acute renal failure. Computed tomography (CT) showed severe stenosis of the true lumen by pressure of thrombus of false lumen, and laboratory data demonstrated renal ischemia. We performed TEVAR succesfully, but severe stenosis of the true lumen remained narrow. So, we added Peripheral self-expanding stent in narrow true lumen. After the operation, patient improved urine output and laboratory data. And narrow true lumen was gradually expanded.

(J Jpn Coll Angiol 2020; 60: 145-149)

Online publication August 10, 2020 